\title{
Operationalizing agency in livelihoods research: smallholder farming livelihoods in southwest Ethiopia
}

\author{
Aisa O. Manlosa ${ }^{1}$
}

\begin{abstract}
Livelihoods are activities and practices in which social and environmental factors interlink, and they play a key role in achieving human well-being and environmental conservation. Livelihood analyses are therefore important to social-ecological systems research. With a few exceptions, however, the concept of agency has been largely missing in research applying the social-ecological systems approach. This is an important gap to address, because humans are not passive victims of broader sociopolitical trends and environmental changes, but rather play causative roles that shape history. This paper presents a conceptual framework that enables the explicit integration of agency into livelihood analyses, and is useful for examining the extent to which livelihoods enable people to be agents of their own well-being, and stewards of their environment. The framework has four pillars of agency: preconditions (referring to capital assets and resources, or CARs); processes (feedbacks and dynamics); power (the social and political fabrics, and relations in which livelihoods are embedded); and possibilities (the extent to which a present livelihood expands into future options, and builds the ability to act on options). The framework is then applied to a case study analyzing smallholder farming livelihoods and food security in southwest Ethiopia. The case study is based on empirical work involving quantitative survey, in-depth interviews, and focus-group discussions. This paper demonstrates the applicability of the framework to identifying agency constraints in smallholder farming, and helps determine areas where agency can be further strengthened. Beyond the case study, the framework may also be applied in other contexts and to other livelihood types. Its application can strengthen the contribution of livelihood analysis to social-ecological systems research by providing a way to operationalize and foreground agency.
\end{abstract}

Key Words: agency; agriculture; empowerment; livelihoods; social-ecological systems approach; sustainability

\section{INTRODUCTION}

Sustainable livelihoods enable people to lift themselves out of poverty, meet their food and nutrition requirements, be agents for the improvement of their own and their households' well-being, and be stewards of the environment on which they depend. Thus, livelihood analyses have made important contributions to broader research areas such as those concerned with development, the environment, and sustainability.

Within the broader area of sustainability science, the socialecological systems (SES) approach focuses on the interlinkages of coupled human-environment systems (Folke 2006, Berkes et al. 2008). Social-ecological systems research, particularly within the broader area of sustainability science, is mainly driven by realworld problems and is oriented toward finding solutions (Kates et al. 2001, Fisher et al. 2015). Research topics that have been investigated using an SES approach include biodiversity conservation (Dorresteijn et al. 2015, Fischer et al. 2021), food and nutrition security (Hodbod and Eakin 2015, Wittman et al. 2017), ecosystem services (Nasl and Löffler 2015) and disservices (Blanco et al. 2019), and land-use management (Paz et al. 2020), among others. A commonality between these topics is that they necessitate understanding interactions between the social and ecological dimensions of social-ecological systems. They involve examinations of how people, as individuals and as collectives, interact with, influence, and are influenced by their environments, in the process of going about their daily lives to pursue interlinked goals such as production of food, generation of income, actualization of identity, and reproduction of social relations and community life. Social and ecological interactions and their resulting outcomes concretely play out in people's lived experiences as they practice their livelihoods. Thus, livelihood analysis remains relevant and has much to contribute to socialecological systems research (Shackleton et al. 2021).

In the 1980s, sustainable livelihoods thinking (SLT) aimed to put first the concerns, perspectives, experiences, and interests of the poor in development research, policy making, and practice (Chambers 1987, Chambers 1995). This became the precursor to livelihood research, which became more established in the 1990s. The sustainable livelihoods framework (SLF) is the most widely known approach, and provided a comprehensive and adaptable framework for operationalizing SLT (Scoones 1998). Various other conceptual developments in livelihood analysis followed. For instance, the concept of livelihood trajectories integrates a temporal dimension and provides a way to capture shifts and changes in people's livelihoods over time (e.g., Novotny et al. 2021, Thanh et al. 2021). Archetypes of livelihood vulnerability investigate how social-ecological factors activate processes that generate livelihood outcomes (Oberlack et al. 2016). Other conceptual developments include a more socially embedded conceptualization of capital assets and resources (CARs; van Dijk 2011), the conceptualization of livelihoods as social practices using Bourdieu's theory of practice (Sakdapolrak 2014), critical attention to the role of politics (Scoones 2015), and the incorporation of the capability approach to livelihood analysis (Chowdhury 2021). These have contributed to advancing how livelihoods are researched, and they address limitations of the widely adopted SLF (see Arce 2004, van Dijk 2011, and Sakdapolrak 2014 for some critiques of SLF).

With some exceptions, however, livelihood analysis either as stand-alone research or as part of broader social-ecological systems research mostly adopts an instrumentalist approach 
(Scoones 2009) and misses an explicit integration of the concept of agency. An instrumentalist approach focuses on the material basis and material outcomes of livelihoods, e.g., studies that focus only on the capital assets that function as the building blocks of livelihoods, and outcomes that are measured in terms of income or production levels. This gap in operationalizing agency, in livelihood analysis particularly and in social-ecological systems research more broadly, needs to be addressed, because humans are not passive victims of broader sociopolitical trends and environmental changes (Brown and Westaway 2011) and are not passive recipients of sustainability benefits and costs. Humans are active agents who play causative roles that enable them to shape history (McLaughlin and Dietz 2008).

This paper makes a conceptual contribution to livelihood analysis and social-ecological systems research. It calls attention to the need to foreground agency, which was the core tenet in SLT (Chambers and Conway 1992, Chambers 1995, Sakdapolrak 2014), but became implicit or peripheral to applications of the SLF (Arce 2004). Concretely, this paper aims to provide a conceptual framework to operationalize agency and to demonstrate its application in a case study of smallholder farming livelihoods in southwest Ethiopia.

\section{CONCEPTUAL FRAMEWORK}

Livelihoods are the primary means through which people are able to continuously and consistently secure benefits necessary to meet a range of needs: food, fuel, clothing, shelter, or non-material needs, including a sense of dignity, identity, and self-efficacy (Chambers 1987, Scoones 1998, de Haan and Zoomers 2006). Livelihoods comprise the capabilities, assets (including material and social resources), and activities required for a means of living (Chambers and Conway 1992). A livelihood is sustainable when it can cope with and recover from stresses and shocks, maintain or enhance its capabilities and assets, while not undermining the natural resource base (Scoones 1998).

Agency refers to the capacity of individuals to freely make choices (Brown and Westaway 2011). McLaughlin and Dietz define agency as "the capacity of individuals and corporate actors, with the diverse cultural meanings that they espouse, to play an independent causal role in history" (2008:105). Kabeer (1999) similarly understands agency as being about choice and extends it to include the element of action. She therefore defines agency as the ability to define one's goals and act on them. She further adds nuance to this definition by emphasizing that agency extends beyond observable action and involves the meaning, motivation, and purpose that people bring to their activity. Although she agrees with the tendency in social-science literature to understand agency as decision making, she argues that agency takes various forms, including bargaining and negotiation, non-action as a form of resistance, and often invisible processes of cognitive activity involving reflection and analysis. Drawing on these thoughts, this study defines agency as the ability to freely determine one's goals and to act to achieve these goals. This applies to people's goals and actions in the context of their livelihoods and in other areas of their lives. Agency can be possessed by individuals, and by groups (McLaughlin and Dietz 2008).

As an ability, agency can be diminished or enhanced (Alkire 2007, Carmichael and Rijpma 2017). Thus, different people or groups, at different points in time, may have more or less abilities to determine goals and achieve them. Questions of whose agency, and agency to do what, are important to sustainability (Lundsgaard-Hansen et al. 2018). Given high levels of inequality, and environmental and social injustice evidenced by uneven quality of human well-being, by uneven distribution of wealth, and by differentiated vulnerability to adverse impacts of environmental change, research engaging with agency must seek to understand how the poorest and most vulnerable can be better supported in fulfilling their roles as agents who are able to lift themselves out of poverty, secure their food and nutrition, and be stewards of their environment, among other things (Narayan and Petesch 2007). Agency-centered research would reinstate the intention of livelihood research (Chambers 1987), which involves searching for methods that are more effective in supporting individuals and communities in meaningful ways that align with their daily lives and needs (Appendini 2001).

To operationalize the concept of agency, I propose four multiscale pillars. The content of these pillars is not new; they have been considered at length in various livelihood analyses and social-ecological systems research. However, identifying these pillars provides a way of bringing together and systematically analyzing issues previously dealt with using separate approaches. These pillars are preconditions, processes, power, and possibilities.

Preconditions refer to the capital assets and resources (CARs) that serve as building blocks of livelihoods (Bebbington 1999, Kabeer 1999). These include economic, human, natural, physical, political, and social CARs (van Dijk 2011). The quantity, quality, and configurations of different CARs determine which livelihoods are realizable options and may be pursued.

Processes pertain to the social and ecological feedbacks and dynamics in livelihoods. In this study, processes refer to the way in which challenges with social and ecological sources result in coping strategies that either maintain or erode households' CARs. The maintenance or erosion of CARs provides the basis for people's livelihoods, and feedback on their agency in the next livelihood cycle, i.e., the production and consumption cycle of smallholder farmers (Manlosa et al. 2019b).

Power is concerned with the social and political fabrics in which livelihoods are embedded (Carr 2013, Levine 2014). This study specifically focuses on social and gender norms, including power relations that shape access to and control over CARs, voice in decision making, and freedom to participate in livelihood activities (Petesch et al. 2018, Lawless et al. 2019). Power, as a concept, can be used as a starting point to further analyze empowerment and disempowerment (Kabeer 1999), which are important to the discourse on social justice.

Finally, agency in livelihoods is concerned with possibilities. With rapid environmental changes observed in different parts of the world, livelihood analysis needs to expand beyond questions of people being able to continue on with their present livelihoods. It must also consider whether present livelihoods expand people's future options and strengthen people's abilities to act on their options (Prado et al. 2015). Possibilities can be considered as an outcome that results from the interactions of preconditions, processes, and power. These pillars are broad and malleable and may be further fleshed out depending on the livelihoods and 
context studied. A general question that may be asked in relation to these pillars is whether their characterization in any given case advances or impedes people's ability to be agents of their wellbeing and stewards of their environment.

\section{METHODS}

The case study on smallholder farming livelihoods presented here is located in the highlands of Jimma Zone in southwest Ethiopia (Figs. 1 and 2). It includes six kebeles (the smallest administrative unit in Ethiopia) located in three woredas or districts (i.e., Gumay, Setema, and Gera). Although the conceptual framework applies to various contexts, different types of livelihoods, and research focusing on various sustainability challenges, this case study was selected because (1) smallholder farming livelihoods directly depend on the environment and smallholders are directly affected by environmental changes (Williams et al. 2018); (2) high levels of poverty and food insecurity are observed in smallholder farming households, particularly in sub-Saharan Africa (Food and Agriculture Organization of the United Nations et al. 2020), where loss of biodiversity is also a major concern; and (3) smallholder farming is a livelihood in which improvements in agency can have substantive effects on food security, other aspects of human well-being, and environmental stewardship (Chappell 2018).

Fig. 1. Map of study area showing Jimma Zone and the six kebeles (the smallest administrative unit in Ethiopia).

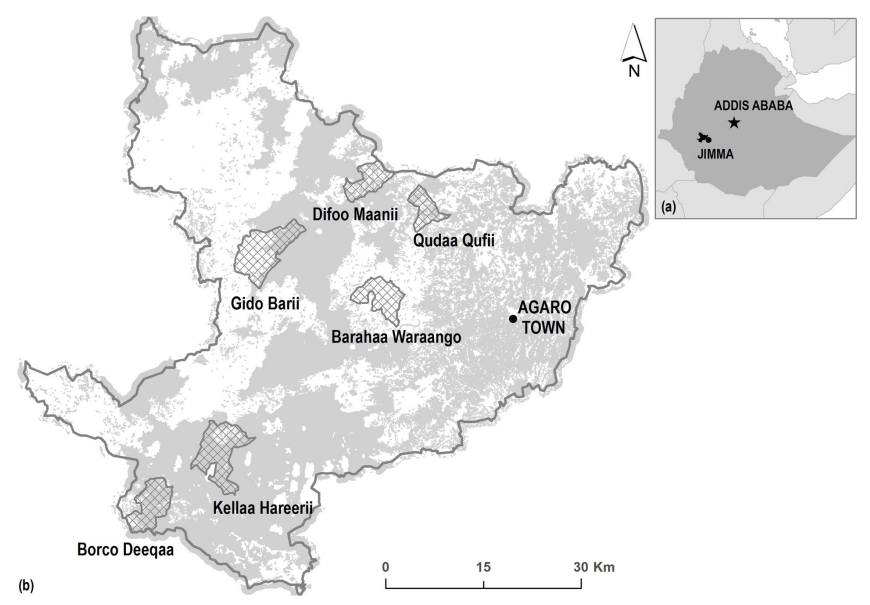

The southwest part of Ethiopia consists of large tracts of Afromontane forests that are important for plant and animal biodiversity (Rodrigues and Fischer 2018, Shumi et al. 2019), and are sources of ecosystem services such as firewood, honey, and spices that many households depend on (Schultner et al. 2021). The forests are also a habitat to the wild gene pool of Arabica coffee (Rodrigues and Fischer 2018) that provides significant foreign exchange for the country and livelihoods for local populations. Because of rainfall levels, this area supports agricultural crop and livestock production.

Food crops such as maize, teff, and wheat are produced for household subsistence and the market. Coffee and khat are the two most important cash crops. Other livelihoods in various parts of the study area, including the collection of honey, production of pulses, livestock, and farm and non-farm labor, are also undertaken. Most households engage in diversified livelihoods that combine crop production with other income-generating activities. However, the production of diverse crops is the most common and is considered to be the most important livelihood by local residents. The majority of the population belong to the Oromo ethnic group and are Muslims (Manlosa et al. 2019a).

Fig. 2. Women in a community market.

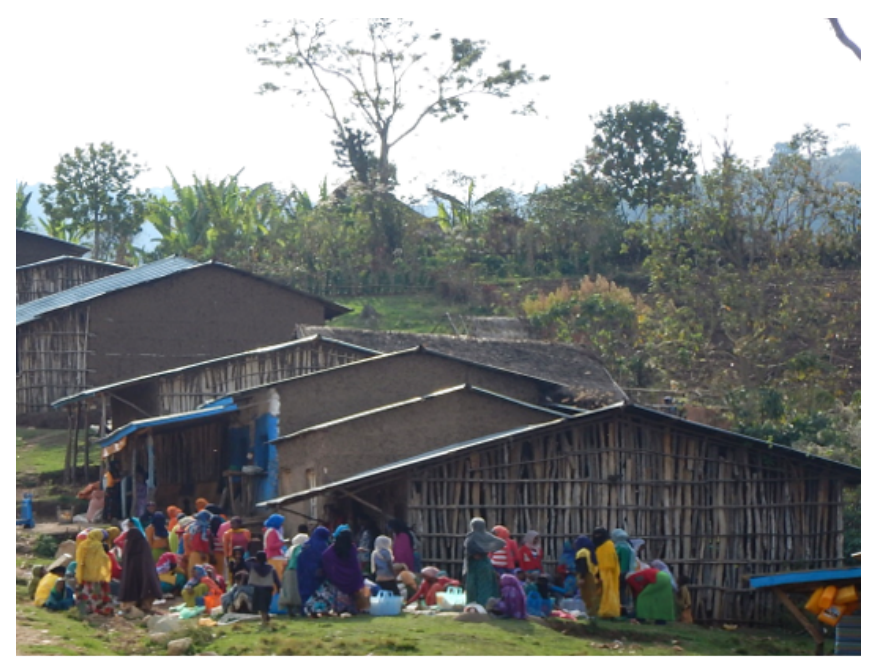

The findings presented in this paper are based on two field seasons (November 2015 to March 2016, and February to March 2017). The first field work involved a quantitative survey of over 360 randomly selected households to characterize households' livelihoods and in-depth interviews with a subset of 30 interviewees to explore social and ecological livelihood challenges and the different ways through which better-off and worse-off households coped with the challenges. The second season of field work focused on the sociocultural and political context in which livelihoods were embedded. This involved 20 focus group discussions with over 150 men and women to investigate how social norms, intersectional gender relations, and power relations shape access and control over resources, decision making, and participation in various livelihood activities. Quantitative and qualitative data were analyzed using different methods and resulted in a number of publications (Table 1). This paper reflects on the concept of agency using the conceptual framework presented earlier, and knowledge of the case study using findings from earlier publications on the study area. In particular, findings from the publication on capital assets and livelihood strategies were used as a basis to reflect on the pillar of preconditions. The publication on livelihood challenges and coping strategies informs the subsection on processes. Findings from the publication on gender and human well-being were used to reflect on power. Finally, I bring together the different findings to reflect on what they imply for the pillar possibilities.

\section{AGENCY IN SMALLHOLDER FARMING LIVELIHOODS IN SOUTHWEST ETHIOPIA}

\section{Preconditions}

Although nearly all households were engaged in diversified smallholder farming, the type of livelihood strategies that 
Table 1. Scientific publications from which findings in this study draw.

\begin{tabular}{|c|c|c|c|c|}
\hline Title & Aims & Methods & Journal & Citation \\
\hline $\begin{array}{l}\text { Livelihood strategies, capital } \\
\text { assets, and food security in rural } \\
\text { Southwest Ethiopia }\end{array}$ & $\begin{array}{l}\text { Characterize livelihood strategies, } \\
\text { determine how capital assets are } \\
\text { associated with livelihood strategies, and } \\
\text { examine how livelihood strategies differ } \\
\text { in food security outcomes }\end{array}$ & Survey (quantitative) & Food Security & Manlosa et al. 2019a \\
\hline $\begin{array}{l}\text { Capital asset substitution as a } \\
\text { coping strategy: practices and } \\
\text { implications for food security and } \\
\text { resilience in Southwest Ethiopia }\end{array}$ & $\begin{array}{l}\text { Examine how smallholder farming } \\
\text { households cope with livelihood } \\
\text { challenges and determine how coping } \\
\text { strategies change households' capital } \\
\text { asset base }\end{array}$ & $\begin{array}{l}\text { In-depth interviews } \\
\text { (qualitative) }\end{array}$ & Geoforum & Manlosa et al. 2019b \\
\hline $\begin{array}{l}\text { Leverage points for improving } \\
\text { gender equality and human well- } \\
\text { being in a smallholder farming } \\
\text { context }\end{array}$ & $\begin{array}{l}\text { Examine social and gender norms and } \\
\text { how they changed }\end{array}$ & $\begin{array}{l}\text { In-depth interviews and } \\
\text { focus group discussions } \\
\text { (qualitative) }\end{array}$ & $\begin{array}{l}\text { Sustainability } \\
\text { Science }\end{array}$ & Manlosa et al. 2018 \\
\hline $\begin{array}{l}\text { Leveraging livelihoods for a food- } \\
\text { secure future: smallholder } \\
\text { farming and social institutions in } \\
\text { Southwest Ethiopia }\end{array}$ & $\begin{array}{l}\text { Determine how smallholder farming } \\
\text { households and individuals in these } \\
\text { households be supported in their roles as } \\
\text { primary agents who are able to improve } \\
\text { their livelihoods and achieve food } \\
\text { security }\end{array}$ & All methods above & $\begin{array}{l}\text { Thesis publicly } \\
\text { available online }\end{array}$ & Manlosa 2019 \\
\hline
\end{tabular}

households undertook differed based on distinct combinations of food crops and cash crops. Livelihoods that included more diverse food crops were associated with better food security. In the order of best to worst food-security outcomes, the livelihood strategies were (1) three food crops (i.e., maize, teff, and sorghum), coffee, and khat, (2) three food crops (i.e., maize, teff, and sorghum) and khat, (3) two food crops (i.e., maize and teff), coffee, and khat, (4) two food crops (i.e., maize and teff) and khat, and (5) one food crop (i.e., maize), coffee, and khat (Manlosa et al. 2019a).

The ability of households to engage in the types of livelihood strategies that resulted in better food security depended on the configurations of CARs that they had access to. The production of diverse food crops was associated with having relatively larger field sizes, more active involvement in informal knowledge sharing with other farmers, ownership of more livestock, and more engagement in sharecropping arrangements for labor access. Having smaller field sizes and owning less livestock (needed as draft animals) limited household production to less diverse food crops, and resulted in worse food security outcomes. With lack of sufficient access and control over CARs that are needed for farming, livelihood strategies that were associated with better food security remained closed off as an option to poorer households, even in a context where livelihoods were broadly similar in terms of being diversified farming livelihoods. Thus, CARs determined the range of realistic options to choose from and act on.

\section{Processes}

CARs did not only function as building blocks of livelihoods, but also influenced the kinds of livelihood challenges and dynamics that households needed to cope with in any given productionconsumption cycle. Challenges, and the coping strategies that people adopted in response, dynamically influenced agency. Coping strategies either maintained or eroded CARs in the process, and generated knock-on effects on agency by maintaining or closing off the livelihood activities and investments that households could pursue (Manlosa et al. 2019b).

Households in the case study typically had to cope with lack of food, sickness in the family, and low harvest either due to low soil fertility, delayed rains, or high crop losses from crop-raiding wild animals, among others. Those who were poorer tended to have less CARs to use for coping, and hence, fewer coping strategies to choose from. They were more likely to cope in ways that resulted in the further erosion of their CARs. An example is the common coping strategy of selling off a livestock to have money for food, or to purchase medicines. Because such a strategy involved a reduction in a key asset that in many cases was not recouped, poor households found themselves in a weaker position for undertaking livelihoods in the following productionconsumption cycle. This resulted in an eventual reduction in harvest. In this context where most households depended on their own production for food, lower harvest raised the likelihood of experiencing hunger later in the year, because fewer food stocks ran out faster. This typically precipitated a cycle of indebtedness and a recurrent need to liquidate remaining assets. The cycle of needing to cope, and losing CARs in the process, increasingly narrowed down options, left smaller room to maneuver, and weakened agency.

Those who were better-off had a markedly different experience. They were not always needing to cope and were able to take proactive measures to secure food supplies. They set aside a portion of their produce and sold the other portions. The income they generated was then used to buy food crops at a time when local supply of food crops was at its highest and prices were low. As the year wore on and local food supply decreased and became more expensive, these households consumed their own stored crops. This proactive measure was not an option for worse-off households who were typically burdened with debts and therefore needed to sell most of their harvest at a season when market prices were low in order to manage timely repayment. With either little 
or no food stocks to rely on throughout the year, those who were poor tended to run out of food and needed to get into debt again to purchase food crops when food had become more expensive. This dynamic process led to worse-off households chronically facing diminishing resources and narrowing options.

Experiences at the household level were embedded within broader forces operating at higher scales. For instance, reduced soil fertility and crop raiding by wild animals were prevalent at the landscape level and were experienced both by better-off and worse-off households. Government rules that required farm owners to apply synthetic fertilizers or risk losing access to state-owned farmland also led to the liquidation of CARs by households. Because use of synthetic fertilizers did not always result in improved harvest, such liquidation also tended to result in loss instead of profit.

Drawing on social capital was one important coping strategy that avoided a reduction in CARs. Crop raiding by wild animals led to loss of as much as half a farm's harvest and this had a negative impact on food security. Social capital enabled a community initiative that pooled together farm labor. In a community arrangement called didaro, households with adjacent farms synchronized their farming timelines and their choice of crops. They assigned farm edges for different households to guard. This strategy reduced the labor burden for each household and prevented significant loss of crops.

\section{Power}

The farming livelihoods were embedded in broader sociocultural and political structures. The intersection of gender with socioeconomic status created distinctive social hierarchies and asymmetric power relations that underpinned the differentiated lived experiences and agency of women and men (Manlosa et al. 2018, Manlosa 2019).

Important strides have been taken in Ethiopia toward achieving gender equality through formal institutional changes. For instance, changes in inheritance laws and the family code provided legal means for daughters to inherit land and divorced or widowed women to retain access to land after losing a husband through divorce or death. However, culturally rooted informal institutions in the form of tacit social norms continued to disadvantage women. In practice, daughters were still expected to gain access to land through marriage and were not likely to inherit land, unlike sons. Divorced or widowed women incurred heavy costs and faced hurdles to legally fight to keep their land, often in offices in town centers far from their homes, and not always with success. The constraints women faced in accessing land meant that their abilities to engage in farming livelihoods were contingent on their relations with men, either through their fathers, husbands, or other male relations.

Gender norms not only determined who can own what, but also who can do what. Decision making in relation to livelihoods was found to have changed from being exclusively a man's role to one that was increasingly shared by more husbands and wives. However, wives' participation in decision making tended to relate more to the practical aspect of how much of the harvest to set aside and allocate for food, and less on strategic decisions about how to use CARs and which livelihoods to undertake. For instance, major decisions such as liquidating livestock for the purpose of accessing medical care was perceived as something that men should decide on. Although women could inform their husbands about the crop that they would like to grow in a certain growing season, husbands typically made these decisions and, in some cases, in consultation with other men in their communities to account for risks from crop-raiding wild animals.

Farm activities such as ploughing were considered to be exclusively men's activities. This effectively limited women's access to primary farm labor through their husbands and sons, and, if they had none, through male relatives or hired males from nearby villages. When they had to hire labor, women often faced competition in access to labor and experienced delays in the ploughing of their farms that had negative effects on harvests and food security. On the other hand, at no point did men mention problems with accessing or competing for labor.

Even though these lived experiences were widespread, they were not uniformly experienced by women. The experiences were mediated by age, social status, and economic status. For instance, female household heads were better able to strategically decide on livelihoods than married women whose husbands were the primary decision makers. Older widowed women tended to have more influence relative to younger women, although adult sons typically took over livelihoods when a male household head passed away. Nevertheless, in general, female-headed households tended to be less food secure than male-headed households.

Social disadvantages were not just strongly experienced by women. Poor, landless men also faced distinct disadvantages. They were more likely to engage in sharecropping arrangements as a means to access land. With their position as laborcontributing sharecroppers, they tended to have the weaker voice in decision making regarding which crops to plant. This constraint in decision making had direct implications for food security. Better-off men who owned other fields in which they planted other food crops, tended to prefer the crop teff because of its high price in the market. This was not preferred by landless men who wanted maize for subsistence. Unequal decision making resulted in poor, landless men being unable to undertake farming in a way that served their goals because they needed to follow the decision of the better-off and landed farmers. They were also likely to bear heavy costs from crop losses on account of wild-animal raiding because they were responsible for guarding the farm. Their access to land was insecure because such arrangements were informal and may be changed by the land owner. All land in Ethiopia is owned by the state, but farmers who have land certificates have formal usufruct rights and sharecrop with landless farmers.

\section{Possibilities}

The importance of farming livelihoods, available resources, and existing infrastructure suggest that livelihood options in the area are still largely going to be related to farming in the foreseeable future. With the livelihood challenges and CARs-eroding dynamics of livelihood processes experienced by the poorest households, particularly women and landless men, opportunities to make farming more profitable for the farming households or to transition out of farming livelihoods are limited. In the face of environmental change that may affect farming, transitioning to other livelihoods as an adaptation strategy will be difficult, unless key constraints discussed above are addressed.

Other livelihood options include trading agricultural goods and livestock. These were found to be profitable but were only an option to a few who were able to meet significant costs for starting 
up. Other possibilities were migration to a different area to find non-farming livelihoods, or to find better access to farmland and to continue farming. Migration, whether to find a job abroad or to start a small business in another place, required financial capital that was typically met with the help of family or relatives.

\section{DISCUSSION}

This study argues for explicitly integrating the concept of agency into livelihood analysis to move beyond the more dominant instrumentalist operationalization of the SLF, and to strengthen the contribution of livelihood analysis to social-ecological systems research. Four pillars of agency, i.e., preconditions, processes, power, and possibilities, were examined in a case study of smallholder farming livelihoods in southwest Ethiopia. The case study demonstrated that lack of the necessary combination of CARs prevented some households from pursuing livelihood strategies with more diverse food crops that had better foodsecurity outcomes. The coping strategies of households to different kinds of challenges either maintained or eroded their CARs and their agency over time. For poor households, liquidation of livestock without commensurate return and the inability to take proactive measures to ensure access to food contributed to their food insecurity. Restrictive gender norms disadvantaged women in terms of access to CARs, their participation in decision making, and their participation in livelihood activities. Women do not form a homogenous group and their experiences differed based on other social characteristics. In general, however, women's agency was highly restricted relative to men's. The outcome was that female-headed households were less able to make their households food secure. Given the challenges, dynamics, and social and political fabrics in which livelihoods in the case study were undertaken, future options to adapt or transition out of unsustainable livelihoods remained limited for the poorest and most vulnerable.

The application of the framework in the case study shows how research and development interventions that are aimed at improving and strengthening livelihoods, particularly smallholder livelihoods, need to engage with multiple dimensions (Chambers 1987, van Dijk 2011, Sakdapolrak 2014). Social-ecological systems research has, to varying extents, addressed the pillars identified in the framework presented here. For instance, studies applying a social-ecological systems approach with a focus on natural resources and ecosystem-service flows and their importance for people's livelihoods comprise an established knowledge area (Reed et al 2015). This speaks to the preconditions of agency. The same can be said of studies dealing with the feedbacks and dynamics of social-ecological systems (Orchard et al. 2014) that play out in the microcosm of individuals' and households' livelihood processes. Critical analyses of the role of social relations and social embeddedness, politics, and power have also been examined at length (Bebbington 1999, Kabeer 1999, Scoones 2015). In various strands of SES research, connections between these research areas are being developed and the importance of agency is already being articulated (Brown and Westaway 2011). However, there is still some way to go to ensure that analyses of livelihoods in SES do not focus disproportionately on resources, but equally take into account dynamics, power, and future possibilities.

Taking account of future possibilities in livelihood analysis means ensuring that people's agency is increasingly strengthened so that they are not only able to meet their needs and achieve well-being in the present, but also safeguard this ability well into the future. Such a future perspective may be relevant to debates, such as those on land grabs (Neef 2021) or concerning which way of agricultural production is most conducive to achieving food security (Kremen 2015). In the absence of an explicit consideration of agency, recommendations or alternative solutions will have a tendency to focus on technocratic or top-down approaches that minimize or ignore the centrality of people (Chappell 2018). This has also been observed in fortress conservation narratives (Siurua 2006, Rai et al. 2021) that prioritize biodiversity conservation and result in the exclusion of people, or the industrialization and intensification of agriculture to increase food production while dispossessing smallholders and destroying their livelihoods (Loos et al. 2014). Human agency needs to be at the forefront of these discussions. The framework developed and explored in this paper is one of various ways that such an important concept is operationalized.

Furthermore, the conceptual framework presented here provides an approach to diagnose whether and how people's agency in their livelihoods, and in their lives more broadly, is being constrained. This helps identify areas requiring action. For instance, this study revealed that food security depends on the kinds of livelihoods that people pursue. However, abilities to pursue certain livelihoods are highly contingent on being able to sufficiently access and control land. People do not have equal opportunities to have this access and control. In practice, women are generally excluded and landless men have access but little to no control. Such a diagnosis highlights that there are multiple areas of action that will need to be simultaneously engaged with, including, for instance, improvement of access to land and other necessary CARs, ensuring that coping strategies responding to livelihood challenges at the very least maintain CARs, and that drivers of social and gender inequalities are transformed.

\section{CONCLUSION}

Livelihoods activities through which people secure their wellbeing and interact with their environment involve agency. Livelihoods are important for understanding the sustainability challenges and outcomes observed in SES. Despite the central importance of agency to livelihoods specifically, and to SES more broadly, it has received less attention and this has the tendency to result in sustainability solutions that are top-down or technocratic. Agency, or people's ability to set their goals, to choose, and to act on their choices, needs to be in the foreground in discourses concerning human well-being and stewardship of the environment. Agency can be refracted and examined through the four pillars of preconditions, processes, power, and possibilities. This conceptualization has been examined in this paper in smallholder farming livelihoods, but it is widely applicable to other livelihood types and other contexts. Readers are invited to critique, test, and expand the proposed framework in their own areas of research and to do so using interdisciplinary and transdisciplinary approaches that foster strong connections between different research areas.

Responses to this article can be read online at: https://www.ecologyandsociety.org/issues/responses. php/12887 


\section{Acknowledgments:}

This work was carried out under a larger interdisciplinary project called Social-ecological System Properties Benefiting Biodiversity and Food Security (SESYP) at Leuphana University Lüneburg (2014-2019). It was funded by the European Research Council through a Consolidator Grant to Joern Fischer.

\section{Data Availability:}

Datalcode available on request, because of ethical restrictions. The datalcode that support the findings of this study are available on request from the author, $A$. O. M. None of the datalcode are publicly available because of restrictions related to the privacy of study participants. Ethical approval for this research study was granted by the Ethics Committee at Leuphana University Lüneburg (EBAntrag Fischer201509 and EB-Antrag Fischer201701-02).

\section{LITERATURE CITED}

Alkire, S. 2007. Measuring agency: issues and possibilities. Indian Journal of Human Development 1(1):169-175. https://doi. org/10.1177/0973703020070110

Appendini, K. 2001. Land and livelihood: what do we know, and what are the issues? Pages 23-28 in A. Zoomers, editor. Land and sustainable livelihood in Latin America. Royal Tropical Institute, Amsterdam, The Netherlands.

Arce, A. 2004. Value contestations in development interventions: community development and sustainable livelihoods approaches. Community Development Journal 38(3):199-212. https://doi. org/10.1093/cdj/38.3.199

Bebbington, A. 1999. Capitals and capabilities: a framework for analyzing peasant viability, rural livelihoods, and poverty. World Development 27(12):2021-2044. https://doi.org/10.1016/S0305-750X (99)00104-7

Berkes, F., J. Colding, and C. Folke, editors. 2008. Navigating social-ecological systems: building resilience for complexity and change. Cambridge University Press, Cambridge, UK. https:// doi.org/10.1017/CBO9780511541957

Blanco, J., N. Dendoncker, C. Barnaud, and C. Sirami. 2019. Ecosystem disservices matter: towards their systematic integration within ecosystem service research and policy. Ecosystem Services 36:100913. https://doi.org/10.1016/j.ecoser.2019.100913

Brown, K., and E. Westaway. 2011. Agency, capacity, and resilience to environmental change: lessons from human development, well-being, and disasters. Annual Review of Environment and Resources 36(1):321-342. https://doi. org/10.1146/annurev-environ-052610-092905

Carmichael, S., and A. Rijpma. 2017. Measuring agency. Pages 51-72 in J. L. van Zanden, A. Rijpma, and J. Kok, editors. Agency, Gender, and Economic Development in the World Economy 1850-2000. Routledge, Oxford, UK.

Carr, E. R. 2013. Livelihoods as intimate government: reframing the logic of livelihoods for development. Third World Quarterly 34(1):77-108. https://doi.org/10.1080/01436597.2012.755012
Chambers, R. 1987. Sustainable livelihoods, environment, and development: putting poor rural people first. Institute of Development Studies Discussion Paper 240, Institute of Development Studies, University of Sussex, Brighton, UK. [online] URL: https://opendocs.ids.ac.uk/opendocs/ handle/20.500.12413/875

Chambers, R. 1995. Poverty and livelihoods: whose reality counts? Environment and Urbanization 7(1):173-204. https://doi. org/10.1177/095624789500700106

Chambers, R., and G. Conway. 1992. Sustainable rural livelihoods: practical concepts for the 21st century. Institute of Development Studies Discussion Paper 296, Institute of Development Studies, University of Sussex, Brighton, UK. [online] URL: https://www.ids.ac.uk/publications/sustainablerural-livelihoods-practical-concepts-for-the-21st-century/

Chappell, M. J. 2018. Beginning to end hunger. University of California Press, Berkeley, California, USA.

Chowdhury, T. A. 2021. Applying and extending the sustainable livelihoods approach: identifying the livelihood capitals and wellbeing achievements of indigenous people in Bangladesh. Journal of Social and Economic Development 23(4):1-19. https://doi. org/10.1007/s40847-021-00163-Z

de Haan, L., and A. Zoomers. 2006. How to research the changing outlines of African livelihoods. Africa Development 31 (4):121-50.

Dorresteijn, I., J. Loos, J. Hanspach, and J. Fischer. 2015. Socioecological drivers facilitating biodiversity conservation in traditional farming landscapes. Ecosystem Health and Sustainability 1(9):1-9. https://doi.org/10.1890/EHS15-0021.1

Fischer, J., A. Bergsten, I. Dorresteijn, J. Hanspach, K. Hylander, T. S. Jiren, A. O. Manlosa, P. Rodrigues, J. Schultner, F. Senbeta, et al. 2021. A social-ecological assessment of food security and biodiversity conservation in Ethiopia. Ecosystems and People 17 (1):400-410. https://doi.org/10.1080/26395916.2021.1952306

Fischer, J., T. A. Gardner, E. M. Bennett, P. Balvanera, R. Biggs, S. Carpenter, T. Daw, C. Folke, R. Hill, T. P. Hughes, et al. 2015. Advancing sustainability through mainstreaming a socialecological systems perspective. Current Opinion in Environmental Sustainability 14:144-149. https://doi.org/10.1016/j.cosust.2015.06.002

Folke, C. 2006. Resilience: the emergence of a perspective for social-ecological systems analyses. Global Environmental Change 16(3):253-267. https://doi.org/10.1016/j.gloenvcha.2006.04.002

Food and Agriculture Organization of the United Nations, International Fund for Agricultural Development, United Nations Children's Fund, World Food Programme, and World Health Organization. 2020. The state of food security and nutrition in the world: transforming food systems for affordable healthy diets. Food and Agriculture Organization of the United Nations, Rome, Italy. [online] URL: https://www.fao.org/3/ ca9692en/online/ca9692en.html

Hodbod, J., and H. Eakin. 2015. Adapting a social-ecological resilience framework for food systems. Journal of Environmental Studies and Sciences 5(3):474-484. https://doi.org/10.1007/ $\underline{\text { s13412-015-0280-6 }}$ 
Kabeer, N. 1999. Resources, agency, achievements: reflections on the measurement of women"s empowerment. Development and Change 30(3):435-464. https://doi.org/10.1111/1467-7660.00125

Kates, R. W., W. C. Clark, R. Corell, J. M. Hall, C. C. Jaeger, I. Lowe, J. J. McCarthy, H. J. Schellnhuber, B. Bolin, N. M. Dickson, et al. 2001. Sustainability science. Science 292(5517):641-642. https://doi.org/10.1002/9781118786352.wbieg0279

Kremen, C. 2015. Reframing the land-sparing/land-sharing debate for biodiversity conservation. Annals of the New York Academy of Sciences 1355(1):52-76. https://doi.org/10.1111/ nyas. 12845

Lawless, S., P. Cohen, C. McDougall, G. Orirana, F. Siota, and K. Doyle. 2019. Gender norms and relations: implications for agency in coastal livelihoods. Maritime Studies 18(3):347-358. https://doi.org/10.1007/s40152-019-00147-0

Levine, S. 2014. How to study livelihoods: bringing a sustainable livelihoods framework to life. Researching Livelihoods and Services Affected by Conflict, Working Paper 22, Secure Livelihoods Research Consortium, Overseas Development Institute, London, UK. [online] URL: https://securelivelihoods. org/publication/how-to-study-livelihoods-bringing-a-sustainablelivelihoods-framework-to-life-2/

Loos, J., D. J. Abson, M. J. Chappell, J. Hanspach, F. Mikulcak, M. Tichit, and J. Fischer. 2014. Putting meaning back into "sustainable intensification." Frontiers in Ecology and the Environment 12(6):356-361. https://doi.org/10.1890/130157

Lundsgaard-Hansen, L. M., F. Schneider, J. G. Zaehringer, C. Oberlack, W. Myint, and P. Messerli. 2018. Whose agency counts in land use decision-making in Myanmar? A comparative analysis of three cases in Tanintharyi region. Sustainability 10(10):3823. https://doi.org/10.3390/su10103823

Manlosa, A. O. 2019. Leveraging livelihoods for a food secure future: smallholder farming and social institutions in southwest Ethiopia. Dissertation. Leuphana University of Lüneburg, Lüneburg, Germany.

Manlosa, A. O., J. Hanspach, J. Schultner, I. Dorresteijn, and J. Fischer. 2019a. Livelihood strategies, capital assets, and food security in rural southwest Ethiopia. Food Security 11 (1):167-181. https://doi.org/10.1007/s12571-018-00883-X

Manlosa, A. O., J. Schultner, I. Dorresteijn, and J. Fischer. 2018. Leverage points for improving gender equality and human wellbeing in a smallholder farming context. Sustainability Science 14 (2): 529-541. https://doi.org/10.1007/s11625-018-0636-4

Manlosa, A. O., J. Schultner, I. Dorresteijn, and J. Fischer. 2019b. Capital asset substitution as a coping strategy: practices and implications for food security and resilience in southwestern Ethiopia. Geoforum 106:13-23. https://doi.org/10.1016/j. geoforum.2019.07.022

McLaughlin, P., and T. Dietz. 2008. Structure, agency, and environment: toward an integrated perspective on vulnerability. Global Environmental Change 18:99-111. https://doi.org/10.1016/ j.gloenvcha.2007.05.003

Nassl, M., and J. Löffler. 2015. Ecosystem services in coupled social-ecological systems: closing the cycle of service provision and societal feedback. Ambio 44(8):737-749. https://doi. org/10.1007/s13280-015-0651-y

Narayan, D., and P. Petesch. 2007. Agency, opportunity structure, and poverty escapes. Pages 1-44 in D. Narayan and P. Petesch, editors. Moving out of poverty: cross-disciplinary perspectives on mobility. World Bank, Washington, D.C., USA.

Neef, A. 2021. Tourism, land grabs, and displacement: the darker side of the feel-good industry. Routledge, Oxford, UK.

Novotny, I. P., M. H. Fuentes-Ponce, S. Lopez-Ridaura, P. Tittonell, and W. A. Rossing. 2021. Longitudinal analysis of household types and livelihood trajectories in Oaxaca, Mexico. Journal of Rural Studies 81:170-181. https://doi.org/10.1016/j. jrurstud.2020.10.022

Oberlack, C., L. Tejada, P. Messerli, S. Rist, and M. Giger. 2016. Sustainable livelihoods in the global land rush? Archetypes of livelihood vulnerability and sustainability potentials. Global Environmental Change 41:153-171. https://doi.org/10.1016/j. gloenvcha.2016.10.001

Orchard, S., L. C. Stringer, and C. Quinn. 2014. Exploring mangrove social-ecological system dynamics in South-East Asia: linking livelihoods, vulnerability, and ecosystem services in Vietnam. Working Paper 169, Centre for Climate Change Economics and Policy, Leeds, UK, and Working Paper 56, Sustainability Research Institute, Leeds, UK. [online] URL: https://www.cccep.ac.uk/publication/exploring-mangrove-socialecological-system-dynamics-in-south-east-asia-linking-livelihoodsvulnerability-and-ecosystem-services-in-vietnam/

Paz, D. B., K. Henderson, and M. Loreau. 2020. Agricultural land use and the sustainability of social-ecological systems. Ecological Modelling 437: 109312.https://doi.org/10.1101/2020.$\underline{07.27 .222422}$

Petesch, P., R. M. Bullock, S. Feldman, L. B. Badstue, A. M. Rietveld, W. Bauchspies, A. Kamanzi, A. Tegbaru, and J. Yila. 2018. Local normative climate shaping agency and agricultural livelihoods in sub-Saharan Africa. Journal of Gender, Agriculture, and Food Security 3(1):108-130.

Prado, D. S., C. S. Seixas, and F. Berkes. 2015. Looking back and looking forward: exploring livelihood change and resilience building in a Brazilian coastal community. Ocean \& Coastal Management 113:29-37. https://doi.org/10.1016/j.ocecoaman.2015.05.018

Rai, N. D., M. S. Devy, T. Ganesh, R. Ganesan, S. R. Setty, A. J. Hiremath, S. Khaling, and P. D. Rajan. 2021. Beyond fortress conservation: the long-term integration of natural and social science research for an inclusive conservation practice in India. Biological Conservation 254:108888. https://doi.org/10.1016/j. biocon.2020.108888

Reed, M. S., L. C. Stringer, A. J. Dougill, J. S. Perkins, J. R. Atlhopheng, K. Mulale, and N. Favretto. 2015. Reorienting land degradation towards sustainable land management: linking sustainable livelihoods with ecosystem services in rangeland systems. Journal of Environmental Management 151:472-485. https://doi.org/10.1016/j.jenvman.2014.11.010

Rodrigues, P., and J. Fischer. 2018. Bird diversity and the resilience of southwestern Ethiopian forests. Tropical Conservation Science 11(1). https://doi.org/10.1177/1940082918781928 
Sakdapolrak, P. 2014. Livelihoods as social practices - reenergising livelihoods research with Bourdieu's theory of practice. Geographica Helvetica 69(1):19-28.https://doi.org/10.5194/gh-69-19-2014

Schultner, J., I. Dorresteijn, A. O. Manlosa, H. von Wehrden, K. Hylander, F. Senbeta, and J. Fischer. 2021. Ecosystem services from forest and farmland: present and past access separates beneficiaries in rural Ethiopia. Ecosystem Services 48:101263. https://doi.org/10.1016/j.ecoser.2021.101263

Scoones, I. 1998. Sustainable rural livelihoods: a framework for analysis. Institute of Development Studies Working Paper 72, Institute of Development Studies, University of Sussex, Brighton, UK. [online] URL: https://www.ids.ac.uk/publications/sustainablerural-livelihoods-a-framework-for-analysis/

Scoones, I. 2009. Livelihoods perspectives and rural development. Journal of Peasant Studies 36(1):171-196. https://doi. org/10.1080/03066150902820503

Scoones, I. 2015. Sustainable livelihoods and rural development. Practical Action, Rugby, UK.

Shackleton, C., K. Schreckenberg, S. Shackleton, and M. Luckert. 2021. Livelihood and vulnerability analysis. Pages 440-450 in R. Biggs, A. de Vos, R. Preiser, H. Clements, K. Maciejewski, and M. Schlüter, editors. Routledge handbook of research methods for social-ecological systems, Routledge, Oxford, UK. https://doi.org/10.4324/9781003021339-38

Shumi, G., P. Rodrigues, J. Schultner, I. Dorresteijn, J. Hanspach, K. Hylander, F. Senbeta, and J. Fischer. 2019. Conservation value of moist evergreen Afromontane forest sites with different management and history in southwestern Ethiopia. Biological Conservation 232:117-126. https://doi.org/10.1016/j.biocon.2019.02.008

Siurua, H., 2006. Nature above people: Rolston and "fortress" conservation in the south. Ethics and the Environment 11 (1):71-96.https://doi.org/10.1353/een.2006.0006

Thanh, H. T., P. Tschakert, and M. R. Hipsey. 2021. Moving up or going under? Differential livelihood trajectories in coastal communities in Vietnam. World Development 138:105219. https://doi.org/10.1016/j.worlddev.2020.105219

van Dijk, T. 2011. Livelihoods, capitals, and livelihood trajectories: a more sociological conceptualization. Progress in Development Studies 11(2):101-17.https://doi.org/10.1177/1464$\underline{99341001100202}$

Williams, P. A., O. Crespo, M. Abu, and N. P. Simpson. 2018. A systematic review of how vulnerability of smallholder agricultural systems to changing climate is assessed in Africa. Environmental Research Letters 13(10):103004. https://doi.org/10.1088/1748-9326/ aae026

Wittman, H., M. J. Chappell, D. J. Abson, R. B. Kerr, J. Blesh, J. Hanspach, I. Perfecto, and J. Fischer. 2017. A social-ecological perspective on harmonizing food security and biodiversity conservation. Regional Environmental Change 17(5):1291-1301. https://doi.org/10.1007/s10113-016-1045-9 